Mycologia, 103(1), 2011, pp. 203-208. DOI: 10.3852/10-137

(C) 2011 by The Mycological Society of America, Lawrence, KS 66044-8897

\title{
A new taxon in the Infundibulicybe gibba complex (Basidiomycota, Agaricales, Tricholomataceae) from Sardinia (Italy)
}

\author{
Alfredo Vizzini ${ }^{1}$ \\ Dipartimento di Biologia Vegetale, Università di \\ Torino, Viale Mattioli 25, 10125 Torino, Italy \\ Marco Contu \\ Via Marmilla 12, 07026 Olbia (OT), Italy \\ Enzo Musumeci \\ Wiesendamm 10a, 4057 Basilea, Switzerland \\ Enrico Ercole \\ Dipartimento di Biologia Vegetale, Università di \\ Torino, Viale Mattioli 25, 10125 Torino, Italy
}

\begin{abstract}
A new species of Infundibulicybe (viz. I. mediterranea sp. nov.) is described from Sardinia based both on morphological and molecular ITS data. The species, a close ally of $I$. gibba, differs from the latter in the darker tinges of the basidiomata, the stipe, which is nearly concolorous with the pileus, and smaller basidiospores. Drawings of the main micromorphological features as well as a color photograph of fresh basidiomata in situ are provided.
\end{abstract}

Key words: Agaricomycetes, Clitocybe gibba, Infundibulicybe catinus, ITS phylogeny, taxonomy

\section{INTRODUCTION}

Infundibulicybe is a genus erected by Harmaja (2003) to accommodate Clitocybe species characterized by mycelia that cannot reduce nitrate, spores that do not adhere in tetrads but exhibit a lacrymoid morphology with confluent base and a cyanophobic spore wall. The genus has occupied an unresolved position in the Agaricales (Redhead et al. 2002, Harmaja 2003, Matheny et al. 2006), but recent work by Binder et al. (2010) indicate Infundibulicybe can be accommodated in the Tricholomatoid clade.

An Infundibulicybe species that has long been known under the informal, unpublished names of "Clitocybe gibba forma mediterranea" or "Mediterranean gibba" is common in the broadleaf forests of northern Sardinia, dominated by Quercus suber and $Q$. ilex. This species is usually eaten by local mycophagists. We have investigated this species to ascertain its relationship with Infundibulicybe gibba

Submitted 5 May 2010; accepted for publication 13 Jul 2010.

${ }^{1}$ Corresponding author. E-mail: alfredo.vizzini@unito.it
(Pers.) Harmaja, a common species in central and northern Europe.

The results of our morphological as well as molecular studies and comparisons have led us to the conclusion that the "Mediterranean gibba" is neither an infraspecific taxon nor a phenotypic expression of $I$. gibba but a species in its own right. The species accordingly is introduced as new to science under the name Infundibulicybe mediterranea. The new taxon is based on a recent collection from Gallura, northern Sardinia, where the fungus is abundant in $Q$. suber woods on granitic acid soil.

\section{MATERIALS AND METHODS}

Morphology.-Descriptions of macro- and microscopic features are drawn from notes of fresh material. The observations of microscopic features were made from mounts of fresh material in $3 \% \mathrm{KOH}$, Congo red, Melzer's reagent and cresyl blue. Spore size is expressed both as a range and a mean value based on 90 randomly chosen spores from spore prints of three specimens. Color notations in the macroscopic descriptions are according to the Flora of British Fungi Colour Identification Chart (1969), hereafter referred to as (Bc). Author citations follow the IPNI Authors Website (http://www.ipni.org/ipni/ authorsearchpage.do) and the Index Fungorum Authors of Fungal Names Website (http://www.indexfungorum. org/authorsoffungalnames.htm). Herbarium abbreviations are according to Thiers (2010). Type material has been deposited at TO (Herbarium generale del Dipartimento di Biologia Vegetale, Università degli Studi di Torino, Italy). The new species name was deposited in MycoBank (http:// www.mycobank.org/DefaultPage.aspx).

DNA extraction, PCR amplification and DNA sequencing.Genomic DNA was isolated from $1 \mathrm{mg}$ dried herbarium specimen from 11 Infundibulicybe gibba collections, one $I$. catinus collection and the type of I. mediterranea (TABLE I) with the DNeasy Plant Mini Kit (QIAGEN, Milan, Italy) according to the manufacturer's instructions. Universal primers ITS1F/ITS4 were used for ITS region amplification (White et al. 1990, Gardes and Bruns 1993). Amplification reactions were performed in a PE9700 thermal cycler (Perkin-Elmer, Applied Biosystems) in $25 \mu \mathrm{L}$ reaction mixtures with these final concentrations or total amounts: $5 \mathrm{ng}$ DNA, $1 \times$ PCR buffer $(20 \mathrm{mM}$ Tris $/ \mathrm{HCl}$ pH $8.4,50 \mathrm{mM}$ $\mathrm{KCl}), 1 \mu \mathrm{M}$ each primer, $2.5 \mathrm{mM} \mathrm{MgCl}_{2}, 0.25 \mathrm{mM}$ each dNTP, 0.5 unit Taq polymerase (Promega). The PCR program was $3 \mathrm{~min}$ at $95 \mathrm{C}$ for one cycle, $30 \mathrm{~s}$ at $94 \mathrm{C}, 45 \mathrm{~s}$ at $50 \mathrm{C}, 2 \mathrm{~min}$ at $72 \mathrm{C}$ for 35 cycles, $10 \mathrm{~min}$ at $72 \mathrm{C}$ for one cycle. PCR products were resolved on a $1.0 \%$ agarose gel and visualized by staining with ethidium bromide. The PCR products were purified 
TABLE I. Species sampled and GenBank accession numbers in this study

\begin{tabular}{|c|c|c|}
\hline Species & $\begin{array}{c}\text { GenBank accession } \\
\text { numbers }\end{array}$ & Source, locality and substrate \\
\hline Infundibulicybe gibba $\mathbf{A}$ & HM631712 & $\begin{array}{l}\text { PA 271, ITALY, Monte Venere, Ronciglione (VT), 07/11/2008, } \\
\text { on Fagus sylvatica litter }\end{array}$ \\
\hline Infundibulicybe gibba $\mathbf{B}$ & HM631713 & $\begin{array}{l}\text { PA 271, ITALY, Stava, Tesero (TN), 08/08/2006, on Picea } \\
\text { excelsa-Pinus sylvestris litter }\end{array}$ \\
\hline Infundibulicybe gibba $\mathbf{C}$ & HM631714 & $\begin{array}{l}\text { PA 271, ITALY, Magnola, Ovindoli (AQ), 23/09/2005, on Fagus } \\
\text { sylvatica litter }\end{array}$ \\
\hline Infundibulicybe gibba $\mathbf{D}$ & HM631715 & $\begin{array}{l}\text { PA 271, ITALY, Monteleone d'Orvieto, Orvieto, 16/11/2008, } \\
\text { mixed wood }\end{array}$ \\
\hline Infundibulicybe gibba $\mathbf{E}$ & HM631716 & $\begin{array}{l}\text { PA 271, ITALY, Cantoniera, Carpegna (RN), 26/09/2001, on } \\
\text { Quercus cerris litter }\end{array}$ \\
\hline Infundibulicybe gibba $\mathbf{F}$ & HM631717 & $\begin{array}{l}\text { PA 271, ITALY, Sughereta di S. Biagio, Monte San Biagio (LT), } \\
\text { 17/11/2006, on Quercus suber litter }\end{array}$ \\
\hline Infundibulicybe gibba $\mathbf{G}$ & HM631718 & $\begin{array}{l}\text { PA 271, ITALY, Campitelli, Civitella Alfedena (AQ), 26/09/ } \\
\text { 2009, on Fagus sylvatica litter }\end{array}$ \\
\hline Infundibulicybe gibba $\mathbf{H}$ & HM631719 & $\begin{array}{l}\text { EM 0340-08, SWITZERLAND, Rodersdorf, Cantone Soletta, 16/ } \\
\text { 08/2008, on Abies alba litter }\end{array}$ \\
\hline Infundibulicybe catinus $\mathbf{I}$ & HM631720 & $\begin{array}{l}\text { EM 2696-06, FRANCE, Linthal, Alsazia, 26/08/2006, on Picea } \\
\quad \text { excelsa litter }\end{array}$ \\
\hline Infundibulicybe gibba $\mathbf{L}$ & HM631721 & PA 271, ITALY, Dimaro (TR), 21/08/2006, on Picea excelsa litter \\
\hline Infundibulicybe gibba $\mathbf{M}$ & HM631722 & $\begin{array}{l}\text { MC1401, ITALY, Sardinia, Abbafritta, Aggius, Olbia-Tempio } \\
\text { Pausania, 15/11/2009, on Quercus suber litter }\end{array}$ \\
\hline Infundibulicybe gibba $\mathbf{N}$ & HM631723 & $\begin{array}{l}\text { MC1400, ITALY, Sardinia, Baldo, Olbia-Tempio Pausania, 06/ } \\
\text { 11/2009, on Quercus suber litter }\end{array}$ \\
\hline Infundibulicybe mediterranea & HM631724 & $\begin{array}{l}\text { TO HG1999, ITALY, Sardinia,16/11/2009, Abbafritta, Aggius, } \\
\text { Olbia-Tempio Pausania, on Quercus suber litter }\end{array}$ \\
\hline Infundibulicybe gibba & AB301608 & GenBank, JAPAN \\
\hline Infundibulicybe gibba & GU188436 & GenBank, USA \\
\hline Infundibulicybe gibba & DQ490635 & GenBank, USA \\
\hline Infundibulicybe gibba & FJ596815 & GenBank, USA \\
\hline Lepista irina & FJ810142 & GenBank, CHINA \\
\hline Lepista nebularis & DQ149728 & GenBank, SLOVENIA \\
\hline
\end{tabular}

with the AMPure XP kit (Beckman) and sequenced by DiNAMYCODE srl (Turin, Italy). The sequences were assembled and edited with the phred/phrap/consed software suite. The sequences were submitted to GenBank (accession numbers are in TABLE I), and the alignments and phylogenetic tree are available at TreeBASE (www.treebase. org) under accession number 10671 (http://purl.org/ phylo/treebase/phylows/study/TB2:S10681).

Sequence alignment and phylogenetic analysis.-Sequences were checked and assembled with Geneious 4.8 (Drummond et al. 2009). Our sequences were aligned together with Infundibulicybe gibba and outgroups sequences retrieved from GenBank (TABLE I). Sequences were aligned with Clustal X 2.0 (Larkin et al. 2007) with default conditions for gap openings and gap extension penalties. Alignments were imported into MEGA 4.0 (Tamura et al. 2007) for manual adjustment. Best-fit models were estimated by both the Akaike information criterion (AIC) and the Bayesian information criterion (BIC) with jModelTest 0.1.1 (Posada 2008) to provide a substitution model for the alignment. Phylogenetic analyses were performed with
Bayesian inference (BI), maximum parsimony (MP) and neighbor joining (NJ). BI was carried out with Monte Carlo Markov chains (MCMC) with MrBayes 3.1.2 (Huelsenbeck and Ronquist 2001). For the alignment analysis four incrementally heated simultaneous MCMC were run over 10000000 generations under model assumptions. Trees were sampled every 1000 generations, resulting in an overall sampling of 10001 trees. The first 2500 trees (25\%) were discarded as burn-in. For the remaining trees a majority rule consensus tree showing all compatible partitions was computed to obtain estimates for Bayesian posterior probabilities (BPP). Branch lengths were estimated as mean values over the sampled trees. Only BPP values exceeding $50 \%$ are reported in the trees. This analysis was repeated three times, always with random starting trees and random starting values for model parameters to test the independence of the results from the revisiting of the prior topologies during chain growth (Huelsenbeck et al. 2002).

$\mathrm{MP}$ and NJ analyses were performed with PAUP* $4.0 \mathrm{~b} 10$ (Swofford 2002). MP analysis was conducted with the heuristic search mode with 1000 random addition sequence replicates and tree bisection reconnection (TBR) branch 

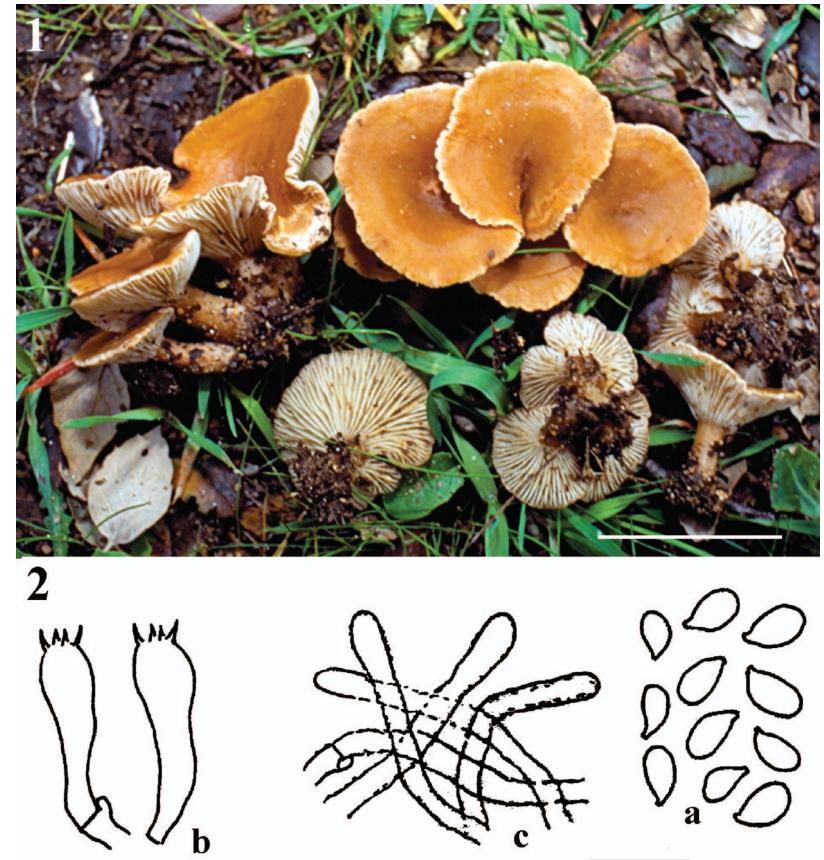

FIGS. 1, 2. Infundibulicybe mediterranea (from holotype, To HG1999). 1. Basidiomata. 2. Microscopic characters. a. Spores. b. Basidia. c. Pileipellis. Bars: $1=5 \mathrm{~cm} ; 2=10 \mu \mathrm{m}$.

swapping, but keeping only 10 trees per replicate to discover possible islands of maximum parsimony. All character states were treated as unordered and equally weighted. Gaps were treated as missing data. Branch robustness was estimated by nonparametric bootstrapping (Felsenstein 1985) with 1000 replicates with 10 random addition replicates per bootstrap. Only bootstrap values exceeding $50 \%$ are visualized in the resulting tree. NJ analysis also was undertaken with the general time reversible (GTR) substitution model. Bootstrap analyses with 1000 replicates also were carried out, and the topology of the NJ tree was interpreted by these categories of bootstrap support: unsupported $(<50 \%)$, moderate (50-85\%) and strong (85-100\%).

Support values for major clades that are supported in either $\mathrm{BI}, \mathrm{MP}$ and $\mathrm{NJ}$ are visualized in the resulting tree. Analysis of the mean p-distances (Nei and Kumar 2000) for the treated Infundibulicybe spp. sequences also were calculated with MEGA 4.0.

\section{TAXONOMY}

Infundibulicybe mediterranea Vizzini, Contu et $\mathrm{Mu}-$ sumeci, sp. nov.

FIGS. 1, 2

MycoBank MB518346

Pileus 1-8 cm latus, elasticus, depressus vel infundibuliformis, leviter umbonatus, brunneus, had striatus, siccus. Lamellae confertae, decurrentes, albae. Stipes $1.5-5 \times 0.3-$ $0.5 \mathrm{~cm}$, sat brevis, cylindricus, ad basim leviter inflatus, levis vel levissime fibrillosus, albo-pruinosus, pileo concolor vel pallidior. Caro elastica, albida, odor saporque gratis. Edulis !
Sporae 4.5-6 $\times$ 3-4 $\mu \mathrm{m}$, hyalinae, sublacrymoideae vel lacrymoideae, leves. Basidia 20-25 × 6-7.5 $\mu \mathrm{m}$, tetraspora. Cystidia nulla. Pilei cutis ex hyphis cylindricis vel subclavatis, laxe intertextis et saepe suberectis, incrustatis, 3-16 $\mu \mathrm{m}$ latis efformata. Fibulae numerosae.

A I. gibba differt coloribus obscurioribus in pileo et in stipite, sporisque minoribus.

Habitat: gregaria, interdum subcaespitosa, ad terram, praecipue in quercetis europaeis meridionalibus obvia.

Typus: Italia, Sardinia, prov. Olbia-Tempio P., Aggius, ad locum dicto Abbafritta, in querceto, 16/XI/2009, leg. A. Vizzini et M. Contu (TO HG1999, holotypus).

Etymology: named in reference to the collection site (viz. Sardinia) in the Mediterranean area.

Pileus 1-8 cm broad, not very fleshy, subelastic, typically plane at first with disk shallowly depressed and margin incurved, often with a small umbo, disk becoming umbilicate or deeply depressed, finally infundibuliform, margin upturned or arched, sometimes lobed or incised and undulate, not hygrophanous, occasionally appearing as hygrophanous due to water soaking, subglabrous to matted fibrillose, rarely diffracted-scaly near the disk, at first dark chestnut brown to brown (Bc 20 dark brick or 19 bay), then paler (Bc 15 brick, 10 cinnamon, 14 rusty-tawny and 13 rust). Surface light brown with a KOH drop in both fresh and dried basidiomes. Lamellae crowded to close, thin, narrow, sometimes forked or intervenose, white; edges even, entire, concolorous. Stipe 1.5-5 $\times$ $0.3-0.5 \mathrm{~cm}$, short, central or subexcentric, equal or with a somewhat enlarged base, concolorous with the pileus or slightly paler (Bc 11 sienne, 13 rust, 10 cinnamon), white-pruinose, glabrous or slightly longitudinally striate, stuffed with white medulla, becoming hollow; the base often with copious white tomentum with adhering leaves and woody debris. Context thin, elastic, white in the pileus, watery brown in the stipe, unchanging. Odor and flavor fungoid; edible, good. Spore print white.

Spores $4.5-6 \times 3-4 \mu \mathrm{m}$, on average $5.5 \times 3.8 \mu \mathrm{m}$, sublacrymoid or lacrymoid in all sides, hyaline, smooth, inamyloid, indextrinoid, acianophilous, with several oil drops and a small apiculus (FIG. 2a). Basidia 20-25 × 6-7.5 $\mu \mathrm{m}$, four-spored, clavate, often with a ventral constriction (FIG. 2b). Hymenophoral trama regular in young stages, but subirregular to irregular in aged basidiomata, made up of hyaline, elongate, cylindrical hyphae. Cystidia and marginal cells absent. Pileipellis a xerocutis made up of loosely interwoven, often protruding brown-encrusted hyphae, these 3-16 $\mu \mathrm{m}$ diam, cylindrical to subclavate (FIG. 2c). Thromboplerous hyphae not seen. Clamp connections present at nearly all septa.

Habitat: scattered, gregarious, often in arcs, occasionally subcaespitose on leaves and humus, under broadleaf trees (Quercus suber, Q. ilex). February- 
TABLE II. Sequence information for ITS alignment

\begin{tabular}{ll}
\hline \multicolumn{1}{c}{ Parameter } \\
\hline Number of taxa & 19 \\
Length of alignment matrix (sites) & 677 \\
Identical sites (\%) & $414(61.2 \%)$ \\
Conserved sites (\%) & $75.2 \%$ \\
Variable sites (\%) & $22.0 \%$ \\
Parsimony informative site (\%) & $11.8 \%$ \\
Pairwise \% identity & $94.4 \%$ \\
GC content (\%) & $38.6 \%$ \\
Gap content (\%) & $3.7 \%$ \\
Model of sequence evolution & $\mathrm{GTR}+\mathrm{G}+\mathrm{I}$ \\
\hline
\end{tabular}

December. Common in Sardinia but seen also in southern France, Corsica and Morocco.

Material studied: Italy, Sardinia, prov. Olbia-Tempio P., Tempio P., Aggius, loc. Abbafritta, under Quercus suber, 16.XI.2009, leg. A. Vizzini et M. Contu (TO HG1999, holotypus).

Descriptive data on the ITS marker.-The ITS1-5.8SITS2 region was sequenced for all taxa investigated, except those whose sequences were taken from GenBank (TABLE I). An overview of alignment length, number of informative and uninformative characters of the ITS is provided (TABLE II). For this marker we used the universal primers ITS1F/ITS4 that produced amplicons 636-661 bp. The aligned data matrix contained $22.0 \%$ variable sites and $11.8 \%$ parsimony informative sites, variation useful for discriminating between Infundibulicybe mediterranea and I. gibba sequences.

Phylogenetic analyses.-Topologies of the trees obtained by the Bayesian Inference (BI), MP bootstrapping and $\mathrm{NJ}$ analysis of the Infundibulicybe spp. sequences are congruent. For this reason only the BI phylogram is shown with the support values for major clades of any analysis (FIG. 3).

The morphological distinction of I. mediterranea in comparison with $I$. gibba is confirmed. The $I$. mediterranea sequence is sister of other Infundibulicybe sequences in all analyses that have been evaluated. This sequence is sister of a clade of European and non-European I. gibba sequences (from USA and Japan). This pattern is supported by

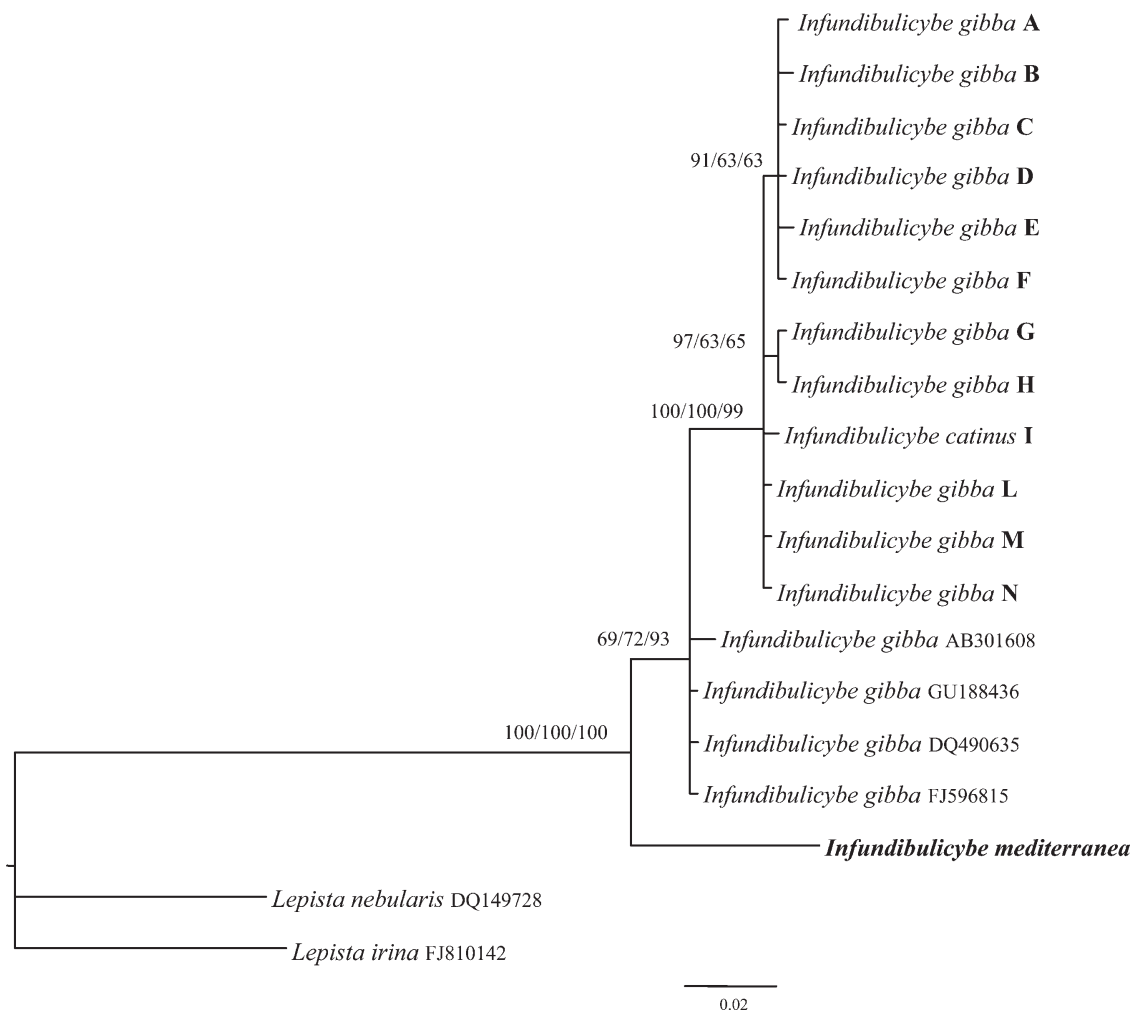

FIG. 3. Bayesian phylogram obtained from the ITS (ITS1-5.8S-ITS2) sequence alignment of Infundibulicibe spp. The GTR + G + I substitution model was used in all phylogenetic analyses. Lepista irina (FJ810142) and Lepista nebularis (DQ149728) were used as outgroup taxa. Support values for major clades that are supported in either the Bayesian (posterior probabilities percentage-BPP), maximum parsimony (bootstrap percentage-MP-BS) and neighbor joining (bootstrap percentage-NJBS) analyses are indicated. BPP/MP-BS/NJ-BS greater than $50 \%$ are given above branches. (A-N refers to the collections in TABLE I.) 
TABLE III. Mean pairwise (p) distances calculated for the Infundibulicybe mediterranea ITS sequence in comparison with the I. gibba sequences

\begin{tabular}{|c|c|c|c|}
\hline & $\begin{array}{c}\text { European } \\
\text { Infundibulicybe gibba }\end{array}$ & $\begin{array}{c}\text { non-European } \\
\text { Infundibulicybe gibba }\end{array}$ & $\begin{array}{l}\text { Infundibulicybe } \\
\text { mediterranea }\end{array}$ \\
\hline European Infundibulicybe gibba & 0 & & \\
\hline Non-European Infundibulicybe gibba & 0.01 & 0 & \\
\hline \multirow[t]{2}{*}{ Infundibulicybe mediterranea } & 0.03 & 0.02 & 0 \\
\hline & Infundibulicybe gibba group & & Infundibulicybe mediterranea \\
\hline Infundibulicybe gibba group & 0.01 & & \\
\hline Infundibulicybe mediterranea & 0.05 & & n.c. ${ }^{\mathrm{a}}$ \\
\hline
\end{tabular}

${ }^{\mathrm{a}}$ n.c. $=$ not calculated.

$69 \%$ BPP, 72\% MP bootstrap and 93\% NJ bootstrap. The pairwise distances between the I. mediterranea ITS sequence and the European and non-European $I$. gibba sequences were respectively 0.03 and 0.02 (TABLE III), suggesting distant genetic relationships and a clear distinction between these taxa. Furthermore the pairwise distances between I. mediterranea and all the European and non-European I. gibba were 0.05. In contrast the I. gibba sequence pairwise diversity within the group was 0.01 (TABLE III). In this group the European sequences are clustered with fully supported BPP, MP-BS and NJ-BS values, suggesting little geographical diversification within $I$. gibba.

\section{DISCUSSION}

Infundibulicybe mediterranea should be regarded as an independent species from I. gibba, according to both molecular and morphological analyses. From a macromorphological point of view I. mediterranea differs strongly from I. gibba in the darker, more chestnut-brown tinges of both pileus and stipe, while the new species micro-anatomically has constantly smaller basidiospores, hardly exceeding $6.5 \mu \mathrm{m}$ long, in contrast to the basidiospores of I. gibba that usually reach 7.5-8 $\mu \mathrm{m}$ long (e.g. Kühner and Romagnesi 1953: (4.5)5-7(8) × 3-5 $\mu \mathrm{m}$; Harmaja 1969: (4.2)5.58(10) $\times(2.4) 3.4-5.4(6.4) \mu \mathrm{m}$; Clémençon 1984: 5$7.5 \times 3.4 \mu \mathrm{m}$; Schwöbel 1984: 5.5-7.5(- 8,3) $\times$ 4.55.5(-6) $\mu \mathrm{m}$; Raithelhuber 1990, 1997, 2004: 5-8 × 3$5 \mu \mathrm{m}$; Kuyper 1995: 5.5-8 × (3.5)4.0-5.0 $\mu \mathrm{m}$; Bon 1997: (5.5)6-8(8.5) × 3.5-5(5.5) $\mu \mathrm{m}$; Horak 2005: 6$8 \times 3.5-5 \mu \mathrm{m}$; Vesterholt 2008: 5.5-8 × 3.5-5 $\mu \mathrm{m})$.

The taxon already had been reported from southern Italy by Bellù (1996) as Clitocybe gibba f. mediterranea (nomen nudum) and more recently recorded from southern France and Corsica (Roux 2006) and Morocco (Moreau 2009). Clitocybe gibba var. cernua H.E. Bigelow, described from USA and segregated from var. gibba on account of the concolorous pileus and stipe, is easily distinguished by the much larger spores, (5-)6-8(-9) $\times 3-5 \mu \mathrm{m}$, in the protolog (Bigelow 1985). Clitocybe gibba var. occidentalis H.E. Bigelow differs in having a bicolorous stipe (white at the apex, concolorous with the pileus below or darkening with handling) and ellipsoid to more or less ellipsoid-oblong basidiospores, 6-8(-8.5) × 3.5-4(-4.5) $\mu \mathrm{m}$ (Bigelow 1985, Gregory 2007).

I. catinus (Fr.) Harmaja, considered by some authors (Kuyper 1995, Bon 1997, Harmaja 2003, Vesterholt 2008) as different from I. gibba because of a white pileus and slightly broader spores $(\times 5-6 \mu \mathrm{m})$ could be only a chromatic variant of the latter, as already suggested by Schwöbel (1984). A sequenced $I$. catinus specimen from France (TABLE I) clearly clusters within the I. gibba collections (FIG. 3). I. gibba sequences retrieved from GenBank (three from USA and one from Japan) probably represent a different, although closely related, taxon (TABLE III, FIG. 3).

\section{ACKNOWLEDGMENTS}

Our most sincere thanks are extended to P. Angeli (Rimini, Italy) for sending well preserved collections belonging to taxa of the I. gibba complex and to P.B. Matheny (Univ Tennessee, Knoxville) and E. Grilli (Popoli, Italy) for improving the English text.

\section{LITERATURE CITED}

Bellù F. 1996. Alcune specie mediterranee di recente identificazione con particolare riguardo al genere Clitocybe. Riv Micol 39(2):99-114.

Bigelow HE. 1985. North American species of Clitocybe II. Beih Nova Hedwig 81:281-471.

Binder M, Larsson K-H, Matheny PB, Hibbett DS. 2010. Amylocorticiales ord. nov. and Jaapiales ord. nov.: Early diverging clades of Agaricomycetidae were dominated by corticioid forms. Mycologia 102:865-880, doi: $10.3852 / 09-288$ 
Bon M. 1997. Flore Mycologique d'Europe 4. Les Clitocybes, Omphales et ressemblants. Amiens: Doc Mycol, Mém Hors-Sèr, vol 4. p 1-181.

Clémençon H. 1984. Kompendium der Blätterpilze. Clitocybe. Z Mykol Beih 5:1-68.

Drummond AJ, Ashton B, Cheung M, Heled J, Kearse M, Moir R, Stones-Havas S, Thierer T, Wilson A. 2009. Geneious v4.8 (Available from http://www.geneious. com).

Felsenstein J. 1985. Confidence-limits on phylogenies-an approach using the bootstrap. Evolution 39:783-791, doi: $10.2307 / 2408678$

Flora of British Fungi Colour Identification Chart. 1969. Edinburgh: Royal Botanic Garden.

Gardes M, Bruns TD. 1993. ITS primers with enhanced specificity for basidiomycetes-application to the identification of mycorrhizae and rusts. Mol Ecol 2(2):113118, doi:10.1111/j.1365-294X.1993.tb00005.x

Gregory DC. 2007. The genus Clitocybe of California (master's thesis). San Francisco State Univ. 263 p.

Harmaja H. 1969. The genus Clitocybe (Agaricales) in Fennoscandia. Karstenia 10:5-119.

- 2003. Notes on Clitocybe s. lato (Agaricales). Ann Bot Fenn 40:213-218.

Horak E. 2005. Röhrlinge und Blätterpilze in Europa. München: Elsevier. 555 p.

Huelsenbeck JP, Ronquist F. 2001. MrBayes: Bayesian inference of phylogenetic trees. Bioinformatics 17: 754-755, doi:10.1093/bioinformatics/17.8.754

—, Larget B, Miller RE, Ronquist F. 2002. Potential applications and pitfalls of Bayesian inference of phylogeny. Syst Biol 51:673-688, doi:10.1080/ 10635150290102366

Kühner R, Romagnesi H. 1953. Flore analytique des champignons supérieurs. Paris: Masson. 557 p.

Kuyper TW. 1995. Clitocybe. In: Bas C, Kuyper TW, Noordeloos ME, Vellinga EC, eds. Flora Agaricina Neerlandica. Vol. 3. Rotterdam: A.A. Balkema. p 42-62.

Larkin MA, Blackshields G, Brown NP, Chenna R, McGettigan PA, McWilliam H, Valentin F, Wallace IM, Wilm A, Lopez R, Thompson JD, Gibson TJ, Higgins DG. 2007. Clustal W and Clustal X version 2.0. Bioinformatics 23: 2947-2948, doi:10.1093/bioinformatics/btm 404

Matheny PB, Curtis JC, Hofstter V, Aime MC, Moncalvo JM, Ge ZW, Yang ZL, Slot JC, Ammirati JF, Baroni TJ, Bougher NL, Hughes KW, Lodge DJ, Kerrigan RW, Seidl MT, Aanen DK, DeNitis M, Daniele GM, Desjarden DE, Kropp BR, Norvell LL, Parker A,
Vellinga EC, Vilgalys R, Hibbett DS. 2006. Major clades of Agaricales: a multilocus phylogenetic overview. Mycologia 98:982-995, doi:10.3852/mycologia.98.6.982

Moreau PA. 2009. Révision des Tricholomataceae clitocyboïdes et omphaloïdes. In: Maire J-C, Moreau P-A, Robich G, eds. Compléments à la flore des champignons supérieurs du Maroc de G. Malençon et R. Bertault. Nice, France: Confédération Européenne de Mycologie Méditerranéenne. p 447-492.

Nei M, Kumar S. 2000. Molecular evolution and phylogenetics. New York: Oxford Univ Press. 333 p.

Posada D. 2008. jModeltest: phylogenetic model averaging. Mol Biol Evol 25:1253-1256, doi:10.1093/molbev/ msn083

Raithelhuber JH. 1990. Die Gattung Clitocybe ss. lat. in den ABC-Staaten. Metrodiana 18(1-2):1-72.

— 1997. Trichterlinge Mitteleuropas. Determinationkeys. Metrodiana 24(1-4):99-120.

- 2004. Mitteleuropäische Trichterlinge. Gattungen Clitocybe, Pseudolyophyllum und Paralepista. Stuttgart: J.H. Raithelhuber Außenseiterverlag. 172 p.

Redhead SA, Lutzoni F, Moncalvo JM, Vilgalys R. 2002. Phylogeny of agarics: partial systematics solutions for core omphalinoid genera in the Agaricales (euagarics). Mycotaxon 83:19-57.

Roux P. 2006. Mille et un champignons. Edition Roux, Sainte-Sigolène. 1223 p.

Schwöbel H. 1984. Trichterlinge aus dem C. gibba-Formenkreis. Beitr Kenn Pilze Mittel 1:5-10.

Swofford DL. 2002. PAUP*: phylogenetic analyses using parsimony (*and other methods). Version 4.0b10. Sunderland, Massachusetts: Sinauer Associates.

Tamura K, Dudley J, Nei M, Kumar S. 2007. MEGA4: molecular evolutionary genetics analysis (MEGA) software. Version 4.0. Mol Biol Evol 24:1596-1599, doi:10.1093/molbev/msm092

Thiers B. 2010 [continuously updated]. Index Herbariorum: a global directory of public herbaria and associated staff. New York Botanical Garden's Virtual Herbarium. http:/ /sweetgum.nybg.org/ih/

Vesterholt J. 2008. Infundibulicybe Harmaja. In: Knudsen H, Vesterholt J, eds. Funga Nordica. Copenhagen: Nordsvamp. p 310-312.

White TJ, Bruns TD, Lee S, Taylor J. 1990. Amplification and direct sequencing of fungal ribosomal RNA genes for phylogenetics. In: Innis MA, Gelfand DH, Snisky JJ, White TJ, eds. PCR protocols. London: Academic Press. p 315-322. 